\title{
POTENTIAL USE OF THE E' CENTER AS AN INDICATOR OF INITIAL RESETTING IN TL/ESR DATING OF VOLCANIC MATERIALS
}

\author{
C. Falguères, ${ }^{*}$ D. Miallier, $\dagger$ S. Sanzelle,$\dagger$ J. Faïn,$\dagger$ M. Laurent, ${ }^{*} M$. Montret, $\dagger$ T. Pilleyre $\dagger$ and \\ J.J. Bahain* \\ *Institut de Paléontologie Humaine, UMR 9948 du CNRS, 1, rue R. Panhard, Paris 75013, France \\ †Laboratoire de Physique Corpusculaire, Université Baise Pascal, 63177, Aubière Cedex, France
}

\begin{abstract}
Quartz inclusions embedded in volcanic materials can be used for dating Quaternary volcanoes by TL or ESR methods. For these techniques the initial zeroing by heat is assumed. However, this assumption can sometimes be questioned either because the temperature was not high, like in phreatomagmatic deposits, or because of contamination, like in thin tephra layers. Preliminary observations suggested that the presence of the $E^{\prime}$ center could be an indicator of poor initial zeroing. This possibility was investigated in the present work. Quartz grains from various geological contexts were studied for comparison. Annealing and regeneration of the $E^{\prime}$ center was explored.
\end{abstract}

\section{INTRODUCTION}

The dating of volcanic eruptions is of major interest in geology and prehistory. A number of radiometric methods (K-Ar, Ar-Ar, fission tracks, thermoluminescence, electron spin resonance) have been widely applied in this field. But in some cases, the absence, the difficulty of the extraction of minerals, or commonly the constitution itself of the volcanic samples forbid the application of fission tracks and $\mathrm{K}-\mathrm{Ar}$ methods. The applied methods in this study, TL and ESR, are used on quartz which can be found either in volcanic samples or in sediments baked by lava flows. In addition, they offer the advantage of being applicable to samples younger than 50,000 years.

The aim of this work is to know whether the studied samples have been heated enough at the time of the lava outflow. It is not always obvious because of the possible contamination of some samples with nonheated quartz from the crystalline basement, which has been pulled out during the volcanic event.

The presence (or absence) of the E' center observed by ESR spectroscopy gives some information about the temperature at which the different samples have been heated by the volcanic eruption. In order to check this possibility, several quartzes, from different origin, have been analysed by ESR. A study was made to observe the $E^{\prime}$ center behaviour with thermal annealing and gamma-ray irradiation.

\section{The $E^{\prime}$ Center}

\section{Structural}

Among the numerous defects created by irradiation in quartz, the $E^{\prime}$ center is probably one of the most studied by solid-state physicists during recent years. The $E^{\prime}$ center is created by an atom vacancy in the crystalline lattice. It is identified as an unpaired electron located between two silicon atoms. The first observation of this center was made by Weeks (1956) who thought that $E^{\prime}$ was related to a structural defect in $\mathrm{SiO}_{4}$ tetrahedrons. The most commonly accepted model is that proposed by Feigl et al. (1974). In this model, the unpaired electron is located on a sp $\mathbf{s}^{3}$ orbital of one of the two adjacent silicons to the vacancy. This structural model was confirmed by Griscom and Fowler (1980). An exhaustive bibliography concerning the $E^{\prime}$ center structure is given in Weil (1984).

\section{Spectroscopic features}

In the present work, the $E^{\prime}$ center is observed at a cavity temperature of $300 \mathrm{~K}$. ESR measurements were carried out using a Varian E-109 X band spectrometer. The $g$-value of the $E^{\prime}$ center is equal to 2.00058 and was checked with a DPPH standard for each sample (Fig. 1).

\section{RESULTS AND DISCUSSION}

\section{Natural E' Signal}

First, we observed the presence (or the absence) of the $E^{\prime}$ center in samples having different geological origins and ages, and coming from various French regions. Most of the analysed samples came from volcanic materials or were in direct contact with volcanic effluents. But the presence of the $E^{\prime}$ center was also checked in non-heated samples like dune or fluviatile sands. Table 1 shows the existence of the $E^{\prime}$ center in all the non-heated samples. When it is present, the $E^{\prime}$ center is associated with a broad signal, OHC center, for which the $g$-value is centered at 2.0040. McMorris (1970) concluded that 


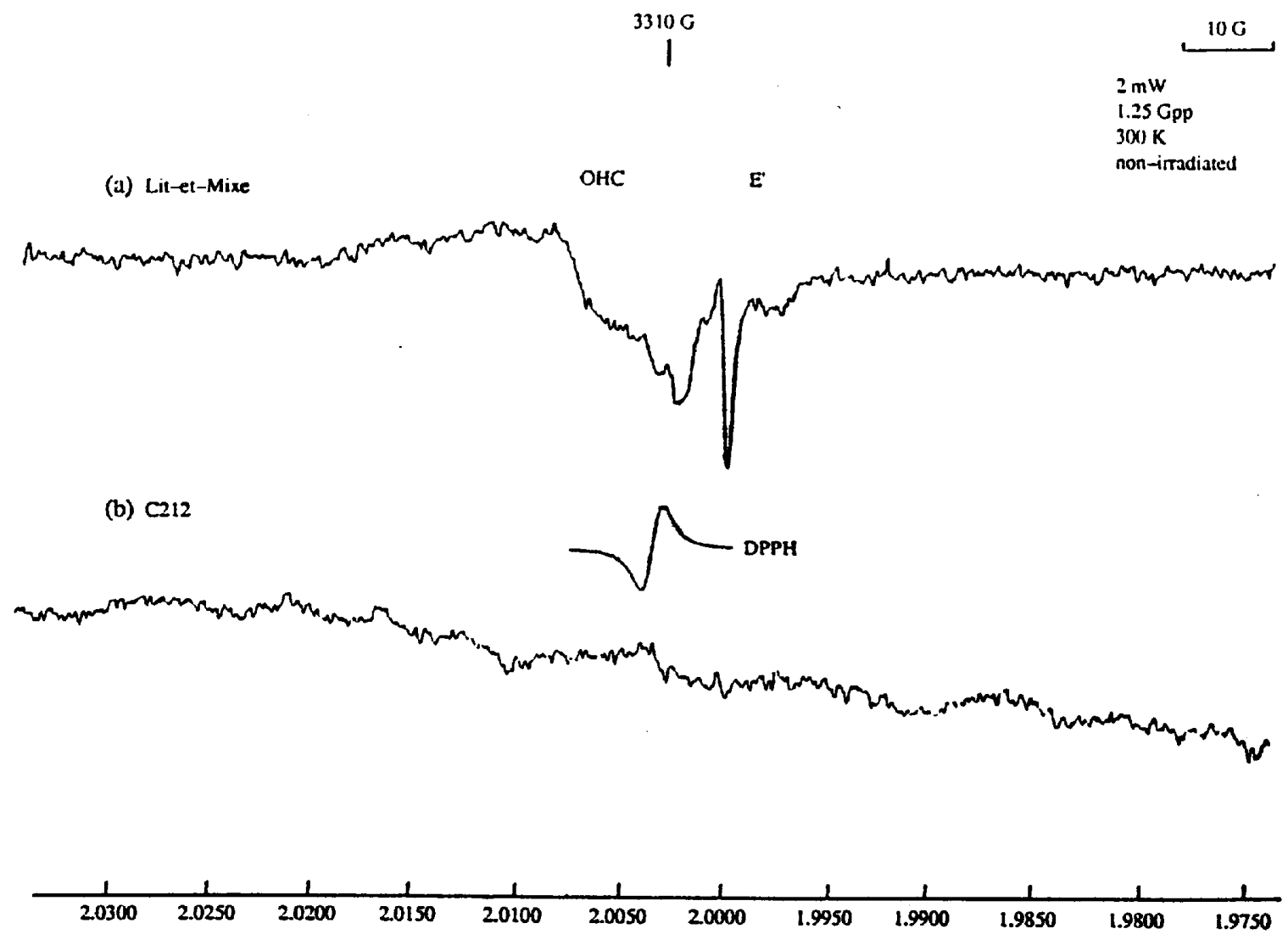

FIG. 1. ESR spectrum of $E^{\prime}$ and $O H C$ centers in non-irradiated quartz samples. The g-value of the $E^{\prime}$ center is checked with DPPH standard $(g=2.0036)$. (a) Quartz sample from sand dune of Lit-et-Mixe, France, without initial heating and showing $E^{\prime}$ and $O H C$ centers. (b) Quartz sample from pumice of Massif Central, France (C212), with high initial heating and where the $E^{\prime}$ center is absent.

TABLE 1. Quartz samples from different origins in which the presence of the $E^{\prime}$ center was checked. This experiment was done in natural and irradiated samples. All the heated samples come from Massif Central and some of them have been dated by the TL and ESR methods (Yokoyama et al., 1985b; Pilleyre et al., 1992)

\begin{tabular}{|c|c|c|c|c|c|c|}
\hline \multirow[t]{2}{*}{ Reference } & \multirow[t]{2}{*}{ Origin } & \multirow[t]{2}{*}{ Assumed age } & \multirow[t]{2}{*}{ Initial heating } & \multicolumn{2}{|c|}{ Non-irradiated } & \multirow{2}{*}{$\begin{array}{l}\text { Irradiated } \\
E^{\prime} \text { center }\end{array}$} \\
\hline & & & & $E^{\prime}$ center & OHC center & \\
\hline $\begin{array}{l}\text { Arago43 } \\
\text { BL20 } \\
\text { C94 } \\
\text { C211 } \\
\text { C212 } \\
\text { C213 } \\
\text { C215 } \\
\text { C220 }\end{array}$ & $\begin{array}{l}\text { aeolian sand } \\
\text { sand beneath tephra } \\
\text { baked sediments } \\
\text { pumice } \\
\text { pumice } \\
\text { baked sediments } \\
\text { baked sediments } \\
\text { phreatomagmatic } \\
\text { deposits }\end{array}$ & $\begin{array}{l}=400 \mathrm{ka} \\
1-2 \mathrm{Ma} \\
=15 \mathrm{ka} \\
=720 \mathrm{ka} \\
=720 \mathrm{ka} \\
\approx 60 \mathrm{ka} \\
=60 \mathrm{ka} \\
=1(00 \mathrm{ka}\end{array}$ & $\begin{array}{l}\text { null } \\
\text { weak or null } \\
\text { high }\left(>500^{\circ} \mathrm{C}\right) \\
\text { high }\left(>500{ }^{\circ} \mathrm{C}\right) \\
\text { high }\left(>500^{\circ} \mathrm{C}\right) \\
\text { high }\left(>5100^{\circ} \mathrm{C}\right) \\
\text { high }\left(>500^{\circ} \mathrm{C}\right) \\
\text { ? }\end{array}$ & $\begin{array}{l}+ \\
+ \\
- \\
- \\
- \\
+\end{array}$ & $\begin{array}{l}+ \\
+ \\
- \\
- \\
- \\
+\end{array}$ & $\begin{array}{l}+ \\
? \\
\dot{?} \\
- \\
- \\
- \\
+\end{array}$ \\
\hline $\begin{array}{l}\text { Cler13 } \\
\text { Ladoux }\end{array}$ & $\begin{array}{l}\text { baked sediments } \\
\text { phreatomagmatic } \\
\text { tephra deposits }\end{array}$ & $\begin{array}{l}\approx 60 \mathrm{ka} \\
\approx 200 \mathrm{ka}\end{array}$ & $\begin{array}{l}\text { high }\left(>5\left(00^{\circ} \mathrm{C}\right)\right. \\
\text { high }\left(>5(0)^{\circ} \mathrm{C}\right) \text { but } \\
\text { possibility of contamination }\end{array}$ & $\dot{+}$ & $\bar{t}$ & $\bar{?}$ \\
\hline $\begin{array}{l}\text { Lit-et-Mixe } \\
\text { Montjuzet }\end{array}$ & $\begin{array}{l}\text { dune sand } \\
\text { tephra layer }\end{array}$ & $\stackrel{?}{=9 \mathrm{ka}}$ & $\begin{array}{l}\text { null } \\
\text { high }\left(>5\left(M^{\circ} \mathrm{C}\right) \text { but }\right. \\
\text { possibility of contamination }\end{array}$ & + & + & + \\
\hline $\begin{array}{l}\text { Nantois } \\
\text { Saint-Saturnin } \\
\text { Tazenat } \\
\text { Terra Amata }\end{array}$ & $\begin{array}{l}\text { acolian sand } \\
\text { baked clay } \\
\text { phreatomagmatic } \\
\text { marine sand of } \\
\text { littoral string }\end{array}$ & $\begin{array}{l}>120 \mathrm{ka} \\
=9 \mathrm{ka} \\
\geqslant 50 \mathrm{ka} \\
\approx 3(x-4) \mathrm{ka}\end{array}$ & $\begin{array}{l}\text { null } \\
\text { high }\left(>5(x)^{\circ} \mathrm{C}\right) \\
\text { high }\left(>5\left(n^{\circ} \mathrm{C}\right)\right. \\
\text { null }\end{array}$ & $\begin{array}{l}+ \\
- \\
+\end{array}$ & $\begin{array}{l}+ \\
- \\
+\end{array}$ & $\begin{array}{l}+ \\
? \\
? \\
+\end{array}$ \\
\hline VNS9103 & tephrs layer & $2(x)-800) \mathrm{ka}$ & $\begin{array}{l}\text { high }\left(>5(x)^{\circ} \mathrm{C}\right) \text { but } \\
\text { possibility of contamination }\end{array}$ & + & + & $?$ \\
\hline $\begin{array}{l}\text { Yssac } \\
\text { La Gardette }\end{array}$ & $\begin{array}{l}\text { detritic sand } \\
\text { hydrothermal }\end{array}$ & $\begin{array}{l}>5 \mathrm{Ma} \\
=5(x) \mathrm{Ma}\end{array}$ & $\begin{array}{l}\text { null } \\
\text { null }\end{array}$ & $\begin{array}{l}+ \\
-\end{array}$ & + & $?$ \\
\hline
\end{tabular}

? Means that these samples have not been irradiated. 
the natural production of this latter signal is due to collisions and displacements caused by the recoiling nuclei of alpha-emitting impuritics. All the quartzes extracted from the sediments baked by lava flows and showing evidence of important heat. like the C94 sample which is a porcellanite, do not present the $E^{\prime}$ center. Some other samples. C220. Ladoux. Montjuzet and VNS9103, show the presence of the $E^{\prime}$ signal. These samples could undergo an initial but insufficient heating or could have been contaminated with older quartzes coming from the crystalline bascment. These samples are usually questionnable for TL and ESR dating as we will see later.

\section{Annealing Studies}

In order to obtain accurate information. a study concerning the behaviour of the $E^{\prime}$ center with regard to thermal annealing and gamma-ray irradiation was made on two samples. The first one is of volcanic origin (C220) and comes from phreatomagmatic deposits in Massif Central. It shows an $E^{\prime}$ signal in the natural sample. The second is of non-heated sedimentary origin (Lit-et-Mixe) and is a dune sand located in the Atlantic coast.

The C220 sample was annealed for $16 \mathrm{hr}$ at different temperatures in order to study the thermal evolution of the $E^{\prime}$ center. The isochronal curve (Fig. 2) shows an increase of the signal intensity from 100 to $250^{\circ} \mathrm{C}$ and a rapid decrease after $250^{\circ} \mathrm{C}$. This curve confirms the results obtained by Jani et al. (19\$3) and recently by Toyoda and lkeya (1991a) for the same center. The latter authors showed. for a volcanic ash. that the increasing intensity of the $E^{\prime}$ center can be corrclated with the decreasing intensity of the Al center (1991b).

On the other hand. the evolution of the $E^{\prime}$ center is studied with regard to the gamma irradiation (Fig. 3). Curve $I$ indicates that the $E^{\prime}$ center intensity decreases slightly and becomes constant when gamma dose increases. This phenomenon was already observed and shows that the $E^{\prime}$ center is often saturated in the natural sample (Yokoyama et al.. 1985a). The same sample was annealed at $370^{\circ} \mathrm{C}$ for $17 \mathrm{hr}$ (curve 2) and reirradiated. The $E^{\prime}$ center intensity grows exponentially with the gamma dose, up to a similar height at which the nonheated sample became constant (dotted line in Fig. 3). This increment was interpreted as a transformation of a non-paramagnetic precursor center, called $E_{p}^{\prime}$, in the $E^{\prime}$ center detectable by ESR spectroscopy (Chatagnon, 1987). The temperature of $370^{\circ} \mathrm{C}$ is not enough to empty completely this precursor, which allows the regeneration of the $E^{\prime}$ center after the second gamma irradiation.

Finally, a study concerning isothermal (Fig. 4) and isochronal (Fig. 5) annealings of the $E^{\prime}$ center was

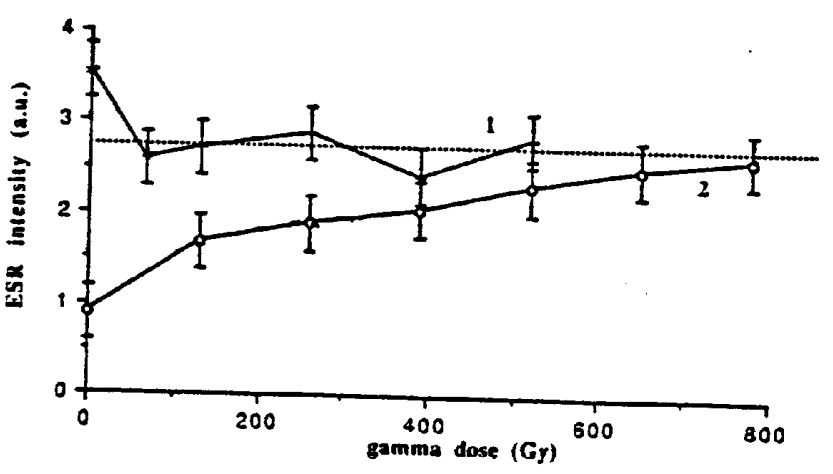

FIG. 3. Growth curves for the $E^{\prime}$ center in C220 sample. Curve 1 corresponds to the behaviour in the non-annealed sample with regard to the gamma irradiation. Curve 2 represents the growth of the $E^{\prime}$ center in the sample which was annealed at $370^{\circ} \mathrm{C}$ for $17 \mathrm{hr}$ and reirradiated with gamma-ray.
FIG. 2. Isochronal annealing curve of the $E^{\prime}$ center from $C_{230}$ sample. The sample has been heated for $16 \mathrm{hr}$ for each annealing temperature. This experiment was done on the natural sample.
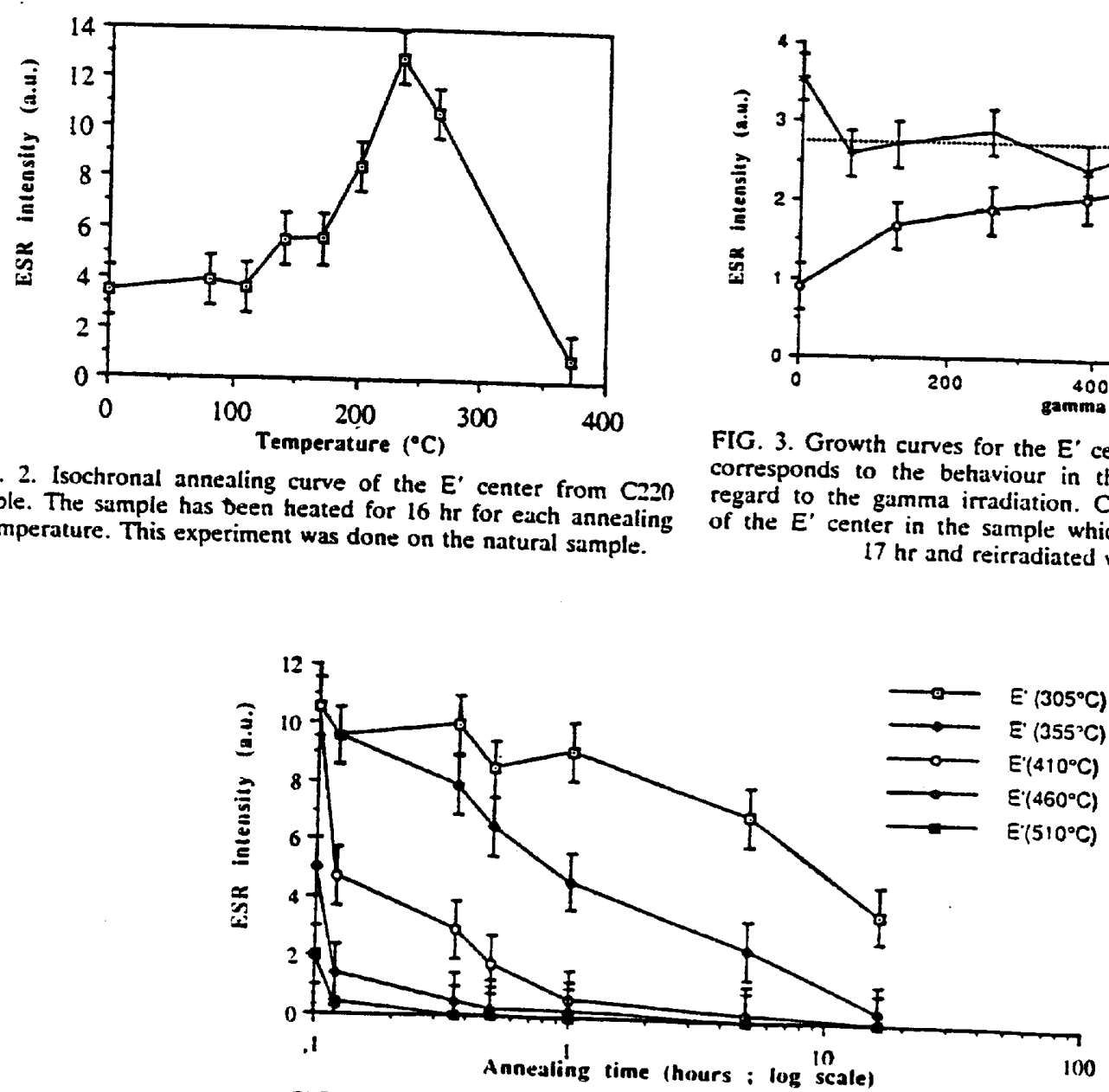

FIG. 4. Isothermal annealing curves for the Lit-et-Mixe natural sample. 


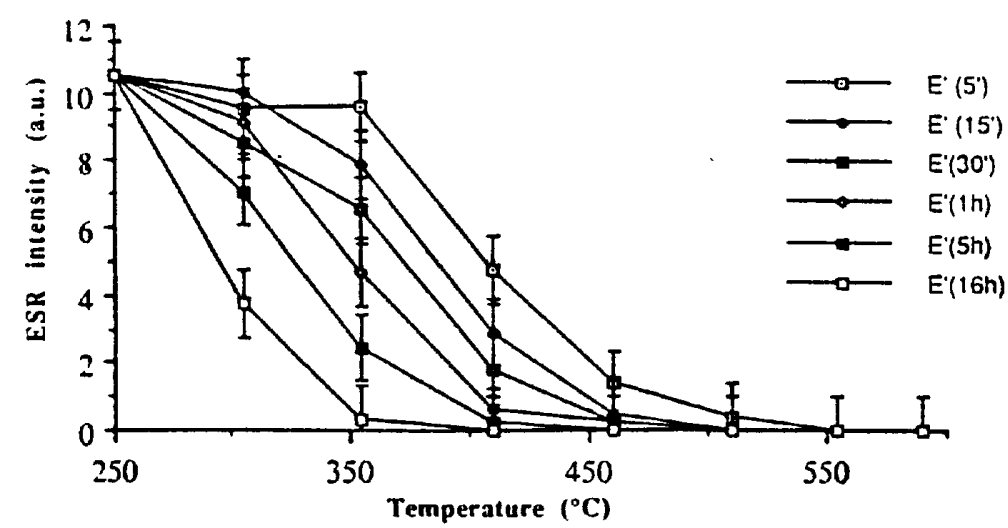

FIG. 5. Isochronal annealing curves for the Lit-et-Mixe natural sample.

realized on the Lit-et-Mixe quartz. The temperature ranged between 300 and $600^{\circ} \mathrm{C}$. The annealing time varies from $5 \mathrm{~min}$ to $16 \mathrm{hr}$. The $\mathrm{E}^{\prime}$ center disappears completely for annealing times higher than $1 \mathrm{hr}$ at a temperature higher than $400^{\circ} \mathrm{C}$. For a temperature higher than $510^{\circ} \mathrm{C}$, the $E^{\prime}$ center is suppressed with an annealing time higher than $5 \mathrm{~min}$.

Isothermal curves (Fig. 4) do not decrease according to an exponential law. Other phenomena may be superimposed to the annealing process of the $E^{\prime}$ center which make the estimation of lifetimes difficult.

The samples annealed at different temperatures were reirradiated at the same gamma dose $(4000 \mathrm{~Gy})$ in order to check the temperature up to which the $E^{\prime}$ center is regenerated. The observation indicates that the $E^{\prime}$ center does not reappear beyond $550^{\circ} \mathrm{C}$ of annealing.

\section{CONCLUSIONS}

These studies concerning the $E^{\prime}$ center yield the following information:

- When the $E^{\prime}$ center is absent in the natural sample and does not appear in the same irradiated sample, the initial heating was higher than $550^{\circ} \mathrm{C}$, and the quartz is datable by TL and ESR methods using centers other than $E^{\prime}$ and $O H C$ centers.

- When the $E$ ' center is absent in the natural sample but appears after irradiation, the initial heating was comprised between 400 and $550^{\circ} \mathrm{C}$. In this case, the ESR and TL dating is also possible using centers other than $E^{\prime}$ and $O H C$.

- When the $E^{\prime}$ center is present in the natural sample, two scenarios are possible:

(i) The initial heating was insufficient and zeroing process is incomplete.

(ii) The initial heating was sufficient but the sample is contaminated with older non-heated quartz from the crystalline basement.

Our study concerns either volcanic samples (pumice) or sediments baked by lava flows. Regarding the hydrothermal quartz of La Gardette (French Alps), the $E^{\prime}$ and $O H C$ centers are not observed in the non-heated natural sample (Table 1). The absence is probably due to the fact that there is practically no alpha irradiation in this kind of quartz.

Our study suggests that the dating of quartz by the $E^{\prime}$ center using gamma-ray irradiation may not be possible, because the increase of the $E^{\prime}$ signal intensity and gamma-ray irradiation is due to a regeneration.

\section{ACKNOWLEDGEMENTS}

We acknowledge B. Morin (laboratoire de spectrochimie, Université de Paris VI) for his help during ESR measurements. We gratefully thank $Y$. Yokoyama for his advice and comments on this paper.

\section{REFERENCES}

Chatagnon, B. (1987). La résanance paramagnétique électronique du centre $E_{\mathrm{t}}{ }^{\prime}$ dans le quartz. Thèse d'Etat présentée à l'Institut National Polytechnique de Lorraine (unpublished).

Feigl, F.J., Fowler, W.B. and Yip, K.L. (1974). Oxygen vacancy model for $E_{1}^{\prime}$ center in $\mathrm{SiO}_{2}$. Solid State Communications, 14, 225.

Griscom, D.L. and Fowler, W.B. (1980) Electron transfer model for $E^{\prime}$ center optical absorption in silicon dioxyde. Proceedings of the International Topical Conference, Raleigh, NC (U.S.A.), pp. 97-101.

Jani, M.G., Bossoli, R.B. and Halliburton, L.E. (1983). Further characterization of the $E_{1}^{\prime}$ center in crystalline $\mathrm{SiO}_{2}$. Physics Review, B27, 2285-2293.

McMorris, D.W. (1970). ESR detection of fossil alpha damage in quartz. Nature, 226, 146-148.

Pilleyre, T., Montret, M., Fain, J., Miallier, D. and Sanzelle. S. (1992). Attempts at dating ancient volcanoes using the red TL of quartz. Quaternary Science Reviews, 11, 13-17.

Toyoda, S. and Ikeya, M. (199/a). Thermal stabilities of paramagnetic defect and impurity centers in quartz: Basis for ESR dating of thermal history, Geochemical Journal, $25,437-445$.

Toyoda, S. and Ikeya. M. (1991b). ESR dating of quartz and plagioclase from volcanic ashes using $E^{\prime}, A l$ and $T i$ centres. Nuclear Tracks and Radiation Measurements, 18, 179-184.

Weeks, R.A. (1956). Paramagnetic resonance of lattice defects in irradiated quartz. Journal of Applied Physics, 27, 1376-1381.

Weil, J.A. (1984). A review of electron spin spectroscopy and its application to the study of paramagnetic defects 
of crystalline quartz. Physics and Chemistry of Minerals, 10, 149-165.

Yokoyama, Y.. Falguères, C. and Quaegebeur, J.P. (1985a) ESR dating of quartz from quaternary sediments: First attempt. Nuclear Tracks and Radiation Measurements, 10, 921-928.
Yokoyama, Y., Falguères, C. and Quaegebeur. J.P. (1985b). ESR dating of sediment baked by lava flows: Comparison of palaeodoses for $\mathrm{Al}$ and $\mathrm{Ti}$ centers. In: Ikeya. M. and Miki, T. (eds), ESR Dating and Dosimetry, pp. 197-204. IONICS, Tokyo. 